\title{
FAKTOR YANG MEMPENGARUHI PENYALAHGUNAAN DOKUMEN KEIMIGRASIAN PENCARI SUAKA DI KOTA MAKASSAR
}

\author{
Factors Affecting the Abuse of Immigration Documents by Asylum Seekers in Makassar City \\ Andi Fikri Fauzi Alimuddin ${ }^{1}$, Ruslan Renggong ${ }^{2}$, Baso Madiong ${ }^{2}$ \\ ${ }^{1}$ Magister Ilmu Hukum Program Pascasarjana, Universitas Bosowa \\ ${ }^{2}$ Program Studi Ilmu Hukum, Program Pascasarjana, Universitas Bosowa \\ Email: fikrifauzi32@gmail.com \\ Diterima: 01 Januari 2021 \\ Dipublikasikan: 07 Juni 0221
}

\begin{abstract}
ABSTRAK
Kota Makassar sebagai salah satu tempat favorit bagi para pengungsi dan pencari suaka sebagai tempat transit sementara sebelum berangkat ke negara tujuan. Fenomena kemunculan pengungsi dan pencari suaka di kota Makassar seringkali dianggap membawa efek negatif bagi negara transit terkhusus Kota Makassar, dimana para pengungsi berpotensi melakukan tindakan-tindakan Penyalahgunaan Izin Keimigrasian serta dari aspek ekonomi akan membebankan Pemerintah karena harus menyediakan fasilitas yang diambil dari pajak masyarakat.. Pemerintah Indonesia tidak mempunyai aturan khusus yang mengatur mengenai perlindungan penanganan dan pengawasan pengungsi dan pencari suaka yang jelas. Hal ini kadang membuat penanganan dan pengawasan pengungsi dan pencari suaka di Kota Makassar tidak berjalan secara maksimal. Metode penelitian yang digunakan adalah Penelitian Lapangan (Field Research) dikombinasikan dengan Penelitian Kepustakaan (Library Research). Populasi dari penelitian ini adalah United Nation High Comission for Refugees (UNHCR) perwakilan Makassar, Kantor Imigrasi kota Makassar, Rumah Detensi Imigrasi kota Makassar dan pengungsi dan pencari suaka yang berada di rumah rumah penampungan sementara di Kota Makassar. Teknik pengumpulan data adalah wawancara dan dokumentasi yang kemudian dianalisis secara kualitatif dan dituangkan dalam bentuk deksriptif. Hasil penelitian menunjukkan bahwa adanya penanganan dan pengawasan pengungsi dan pencari suaka yang berada di kota Makassar yang belum maksimal di karenakan beberapa faktor antaran lain, ketidakjelasan payung hukum pelaksanaan tugas, terbatasnya anggran dalam pemenuhan sarana dan prasarana penanaganan dan pengawasan pengungsi dan pencari suaka di Kota Makassar.
\end{abstract}

Kata Kunci: Penyalahgunaan, Izin Keimigrasian, Pengungsi, Pencari Suaka

\begin{abstract}
Makassar City is one of favorite places for refugees and asylum seekers as a temporary transit point before leaving for the destination country. Phenomenon of the emergence of refugees and asylum seekers in Makassar is often considered to have negative effects on transit countries, especially in Makassar City, where the refugees have the potential to commit the acts of abuse of immigration permits, and in economic aspect this will burden the Government to provide facilities taken from public taxes. The Indonesian government does not have a specific regulation to set the protection of handling and supervision of refugees and asylum seekers clearly. It sometimes makes the handling and supervision of refugees and asylum seekers in Makassar City not running optimally. The research method used is Field Research combined with Library Research. The population of the study were the United Nation High Commission for Refugees (UNHCR) representatives in Makassar, Immigration Office of Makassar, Immigration Detention Center of Makassar, refugees and asylum seekers residing in temporary shelters in Makassar City. Techniques of data collection are interviews and documentation which are then analyzed qualitatively and set forth in a descriptive form. The results showed that the handling and supervision of refugees and asylum seekers in Makassar City was not optimal due to several factors, such as the unclear, legal basis for the implementation of duties, limited budget in fulfilling the facilities and infrastructure for handling and supervision as well as limited officers in handling and supervision of refugees and asylum seekers in Makassar City.
\end{abstract}

Keywords: Abuse, Immigration Permits, Refugees, Asylum Seekers

\section{PENDAHULUAN}

Globalisasi dibarengi dengan kemajuan teknologi, perkembangan teknologi informasi dan transportasi kian meningkat sehingga membuat batas-batas antar negara tidak menjadi kendala untuk dilalui, bahkan jalur lalu lintas antar Negara pun semakin mudah untuk diakses. Semakin terbuka lebarnya jalur lalu lintas antar Negara pada era globalisasi ini menyebabkan meningkatnya pula mobilitas barang dan manusia antar satu negara ke negara lain. Perpindahan penduduk dari satu wilayah negara ke wilayah negara lain dapat merupakan salah satu sebab timbulnya berbagai permasalahan keimigrasian, dan merupakan tantangan yang menghendaki adanya peningkatan kemampuan untuk mengantisipasi arus perubahan yang sangat cepat terjadi. Indonesia sebagai salah satu Negara di dunia juga memiliki potensi yang kuat sebagai tempat persinggahan (transit) ataupun sebagai tempat tujuan para imigran ilegal dikarenakan bentuk negaranya yang memiliki berbagai pintu masuk: bandara, pelabuhan, batas darat dan batas perairan. Hal ini terbukti dengan banyaknya 
kasus-kasus imigran gelap yang terdampar maupun menjadikan indonesia sebagai tempat mencari suaka tanpa memiliki dokumen resmi untuk tinggal di negeri ini. Pengawasan orang asing di Indonesia meliputi masuk dan keluarnya orang asing ke dan dari wilayah Indonesia dan keberadaan serta kegiatan orang asing diwilayah Indonesia. Terhadap warga negara asing pelayanan dan pengawasan dibidang keimigrasian dilakukan berdasarkan prinsip-prinsip yang bersifat selective policy yang artinya hanya orang asing yang dapat memberikan manfaat bagi kesejahteraan rakyat, bangsa dan negara Indonesia serta tidak mengancam atau membahayakan keamanan dan ketertiban umum serta tidak bermusuhan, baik terhadap rakyat, bangsa dan negara kesatuan Republik Indonesia yang berdasarkan Pancasila dan Undang-undang Dasar 1945 yang di izinkan masuk atau keluar wilayah Indonesia. Untuk dapat terwujudnya prinsip yang bersifat selective policy diperlukan pengawasan terhadap orang asing, pengawasan ini tidak hanya dilakukan pada saat mereka masuk tetapi selama mereka berada serta kegiatan mereka diwilayah Indonesia. Hukum Internasional memberikan hak dan kewajiban kepada semua negara untuk menjalankan yurisdiksi kepada semua orang, benda, serta perbuatan yang terjadi didalam wilayah negara tersebut. Setiap negara berhak untuk memutuskan hal ikhwal lalu lintas antar negara. Pengaturan terhadap lalu lintas antar negara adalah berkaitan dengan aspek keimigrasian yang berlaku disetiap negara memiliki sifat universal atau khusus sesuai masing -masing negara sesuai nilai dan kebutuhan negara tersebut

Selain status imigran gelap dikenal juga pencari suaka atau pengungsi yaitu perpindahan manusia, apakah sukarela atau dipaksa, selalu menjadi karakteristik perilaku manusia individu dan kolektif. Pengungsi adalah sekelompok manusia yang sangat rentan terhadap perlakuan yang tidak manusiawi baik di negara asalnya maupun di negara dimana mereka mengungsi Kehidupan sebagai pengungsi memiliki ketidakpastian di negara tujuan dan mereka berada dalam keadaan yang rentan . Migrasi khususnya pengungsi adalah fenomena transnasional dan global yang berpengaruh terhadap stabilitas keamanan baik negara asal, transit dan negara yang menjadi tujuan dari para pegungsi. Masalah yang kompleks terkait erat dengan bidang kebijakan global lainnya, seperti pembangunan, perdagangan, kesehatan, lingkungan, keamanan, integrasi, dan hak asasi manusia.

Sebagai Negara demokrasi yang menjunjung tinggi penghormatan terhadap hak asasi manusia, pemerintah Indonesia wajib memberikan perlindungan hukum tidak hanya terhadap warga Indonesia saja tetapi juga terhadap warga Negara asing yang berada di Indonesia. Di dalam berbagai instrument peraturan nasional, Pemerintah Indonesia selalu menjamin Hak Asasi Manusia. Salah satu bentuk perlindungan hukum bagi warga Negara asing dapat kita temukan dalam Pasal 86 UU No. 6 Tahun 2011 Tentang Keimigrasian, di mana ketentuan tindakan administrasi keimigrasian tidak diberlakukan terhadap korban perdagangan orang dan penyelundupan manusia dan di dalam Pasal 88 Undang-Undang yang sama mengatakan bahwa Menteri atau pejabat Imigrasi yang ditunjuk mengupayakan agar korban perdagangan orang dan penyelundupan manusia yang berkewarganegaraan asing segara dikembalikan ke Negara asal mereka dan diberikan surat perjalanan apabila mereka tidak memilikinya

Kota Makassar sebagai ibukota dari propinsi Sulawesi selatan adalah salah satu Wilayah Republik Indonesia termasuk salah satu daerah tujuan para pencari suaka. Kota Makassar adalah salah satu jalur perdangangan internasional ratusan tahun lalu yang menghubungkan Asia Tenggara, Eropa, Timur Tengah dan Asia. Faktor lainnya yang menarik minat pencari suaka ke Kota Makassar adalah budaya, agama serta ragam makanan yang ada di Kota Makassar tidak jauh berbeda dengan daerah asal mereka sehingga mereka merasa betah di daerah ini. Keberadaan para pencari suaka di Kota Makassar ini menimbulkan permasalahan sendiri bagi keamanan, budaya dan perekonomian di Kota Makassar, banyak terjadi konflik akibat perilaku mereka di masyarakat maupun perselisihan di antara mereka sesama pencari suaka, Hal ini tentunya membawa dampak negatif dalam bidang politik, sosial-budaya dan keamanan di Kota Makassar sehingga pengawasan dan penegakan hukum terhadap imigran gelap sangatlah penting.

\section{METODE}

Kota Makassar merupakan salah satu wilayah yang dipilih oleh pencari suaka. yang terus mengalami peningkatan jumlahnya Selain itu, penduduk kota Makassar yang mayoritas beragama Islam membuat para pencari suaka yang didominasi dari negara Timur Tengah dan beragama Islam tidak kesulitan untuk beradaptasi dengan masyarakat Makassar menggunakan penelitian hukum Deskriptif dengan pendekatan sosio-yuridis artinya disamping adanya penelitian empiris juga digunakan pendekatan hukum untuk mengukur sejauhmana pelaksanaan undang - undang tentang keimigrasian dalam mengangani masalah pencari suaka di Kota Makassar. Data primer ( data empirik) didapatkan melalui wawancara dengan petugas rudenim makassar petugas Kanim Makassar, Pengurus IOM perwakilan Makassar dan beberapa pengungsi dan pencari suaka di rumah penampungan. Data sekunder, diperoleh melalui studi pustaka berupa buku-buku, dokumen, karya ilmiah dan lain-lain yang berkaitan dengan masalah yang diteliti.

\section{HASIL DAN PEMBAHASAN}

Efektifitas Penegakan Hukum Penyalahgunaan Izin Keimigrasian Oleh Pencari Suaka Di Kota Makassar

Kota Makassar merupakan kota terbesar keempat di Indonesia dan terbesar di Kawasan Timur Indonesia. Sebagai pusat pelayanan di Kawasan Timur Indonesia (KTI), Kota Makassar berperan sebagai pusat 
perdagangan dan jasa, pusat kegiatan industri, pusat kegiatan pemerintahan, simpul jasa angkutan barang dan penumpang baik darat, laut maupun udara dan pusat pelayanan pendidikan dan kesehatan. Hal ini menjadi daya tarik tersendiri bagi para pencari suaka memilih Kota Makassar sebagai daerah transit, selain karena keramahan penduduknya, mayoritas agamanya yang muslim, aman dan nyaman untuk tempat bermukim berbagai fasilitas yang mudah dan terjangkau dalam menunjang aktifitas kehidupan mereka selama transit menuju negara tujuan dengan mudah di dapatkan. Imigran di kota Makassar mencapai hampir 20 persen dari total jumlah imigran di Indonesia yang tersebar di beberapa titik penampungan di kota Makassar Para pengungsi dan pencari suaka tersebut berasal dari beberapa negara diantaranya; Afghanistan, Syiria, Yaman, Jordania, Irak, Iran, Palestina, Sudan, Myanmar, Sri Lanka, Somalia, Ethiopia, Somalia, Pakistan, Mesir dan Eritrea. Mayoritasnya adalah berasal dari Afganistan.

Kota Makassar sebagai salah satu kota dengan jumlah pengungsi terbanyak di Indonesia, setiap tahunnya mengalami peningkatan jumlah pengungsi. Pada rentang waktu sekitar 2004-2010 imigran di Makassar masih ditempatkan di Rudenim, belum mengenal sistem akomodasi (penempatan pengungsi di luar Rudenim). Pada 2011 ditandai dengan datangnya pengungsi dari Timur Tengah, Asia, dan Afrika seperti Somalia, Sudan, Afganistan, Iran, Irak, dan Myanmar menjadi awal diberlakukannya sistem akomodasi di Makassar, dengan dibukanya beberapa community house. Saat ini, ada 25 community house, yang tersebar di beberapa titik kecamatan di Kota Makassar . Pada periode 2019, jumlah pengungsi di Makassar yang tinggal di community house sebanyak 1.833, dari total jumlah pengungsi sebanyak 1.854 orang, sisanya tertahan di Rudenim Makassar Data per Oktober 2020 Jumlah migran ilegal atau pencari suaka politik sebanyak 1.671 orang yang tinggal sesuai persyaratan undang-undang, di Kota Makassar, pengungsi dan pencari suaka yang menetap di Indonesia khususnya di Kota Makassar itu masuk melalui Organisasi Internasional untuk Migrasi (IOM) Makassar dan akomodasi atau biaya hidupnya ditanggung sepenuhnya oleh Badan Migrasi PBB itu.

Jumlah pengungsi dan pencari suaka di Kota Makassar per 1 Januari 2019 cenderung mengalami penurununan kuantitas hal ini terjadi karena beberapa faktor antara lain :

1. Sejak akhir tahun 2018 pihak IOM yang berada di Makassar telah menghentikan pembiayaan hidup para pencari suaka di Indonesia, termasuk pencari suaka yang berada di Kota Makassar karena keterbatasan anggaran. Pencari suaka yang datang ke wilayah Indonesia dan Kota Makassar di wajibkan menanggung biaya hidup mereka masing - masing atau mandiri ataupun mencari sponsor lain yang dapat membiayai kehidupan mereka selama di negara transit, tentunya setelah mengantongi Kartu pengungsi dari Badan kemanuaan PBB atau UNHCR.

2. Beberapa orang dari pencari suaka ini dengan sukarela mengajukan diri untuk di pulangkan ke negara asalnya akibat jenuh dan keterbatasan hidup di rumah penampungan sementara tanpa status yang jelas, sementara mereka terkendala tidak menemui kepastian kapan waktunya mereka akan di berangkatkan ke negara tujuan akibat kebijakan selektif dari negara penerima serta alasan ingin dekat dengan keluarga

3. Beberapa orang pencari suaka di pindahkan ke pengawasan dan penanganan Rudenim wilayah lain di Indonesia akibat sikap dan perilaku yang tidak disiplin dan sering melanggar ketentuan yang telah diterapkan oleh pihak rudenim dan IOM makassar selama berada di Community House ( rumah Penampungan ) serta akibat adanya konflik dengan warga sekitar Commmunity House tempat mereka di tempatkan.

4. Rudenim Makassar bersama IOM Makassar telah memberangkatkan banyak pengungsi ke negara tujuan yang menerimanya seusai lolos dari verifikasi negara penerima, antara lain Australia, Selandia Baru, Amerika Serikat dan Kanada. Kelompok pencari suaka yang umumnya lolos verifikasi negara penerima biasanya yang mempunyai tingkat pendidikan yang tinggi dan mempunyai keterampilan khusus semisal pencari suaka yang dahulu di negara asalnya bekerja sebagai guru, dokter, perawat atau ahli konstruksi. Kelompok pengungsi yang tinggal di Community House dan belum jelas kapan mereka akan di terima oleh negara tujuan umumnya memang sejak di negara asalnya tidak mempunyai keterampilan menonjol, umumnya di dominasi oleh petani dan buruh harian lepas kehadiran para pencari suaka di wilayah Kota Makassar tidak terlalu menimpulkan persepsi negatif di tengah masyarakat Kota Makassar. Bahkan di beberapa rumah penampungan para pencari suaka dapat berkomunikasi dan bersosialisasi dengan baik dengan warga sekitar bahkan ikut serta dalam beberapa kegiatan sosial dan keagamaan seperti bersama warga sekitar community house mereka berada melakukan kerja bakti untuk kebersihan dan ikut aktif dalam beberapa kelompok pengajian warga. Informasi mengenai Kondisi Kota Makassar dari berbagai segi menjadi perbincangan tersendiri di kalangan para pencari suaka, dari perbincangan itu akhirnya banyak yang memutuskan pindah dari Rudenim beberapa wilayah di Indonesia menuju Wilayah kerja Rudenim Kota Makassar. Hampir separuh lebih pengungsi dan pencari suaka yang berada di Makassar adalah pindahan dari daerah lain di Indonesia. Beberapa dari mereka, awalnya, berasal dari Rudenim Denpasar, Kantor Imigrasi Kupang, Rudenim Manado, dan kota lain di Indonesia. 
1. Pengawasan dan penanganan pencari suaka di Kota Makassar

Indonesia merupakan salah satu negara yang harus berhadapan dengan permasalahan orang asing pencari suaka dan pengungsi yang masuk dan tinggal di wilayah Indonesia. Meski bukan negara tujuan, dengan konsekuensi letak geografis, negara Indonesia merupakan tempat persinggahan terakhir dari gelombang pencari suaka dan pengungsi untuk ke negara tujuan, yaitu Australia. Indonesia belum menjadi pihak pada Konvensi Tahun 1951 dan Protokol 1967. Dari hal tersebut Indonesia tidak mempunyai wewenang dalam memberikan status pengungsi, sehingga pengaturan permasalahan mengenai pengungsi ditetapkan oleh UNHCR (Komisi Tinggi PBB bidang Pengungsi) sesuai dengan mandat yang diterimanya berdasarkan statuta UNHCR Tahun 1950. Semua negara termasuk yang belum meratifikasi konvensi pengungsi wajib menjunjung tinggi standar perlindungan pengungsi yang telah menjadi bagian dari hukum internasional umum, Penentuan status dilakukan oleh UNHCR yang memakan waktu yang lama. Sehingga dalam waktu menunggu itu terjadi indikasi pelanggaran hak asasi manusia (HAM) seperti perlakuan buruk termasuk serangan fisik, penahanan terhadap pencari suaka dalam waktu yang panjang dan tanpa alasan yang sah dan prosedur interogasi yang kasar. Pemerintah dapat pula gagal untuk memberikan perlindungan yang layak bagi pencari suaka dan pengungsi, sehingga dengan demikian mengekspos mereka pada bahaya serangan rasis dan bentuk kekerasan lainnya.

Ketidaksiapan Indonesia Dalam Menangani Pengungsi Internal Hambatan yang ditemui dalam penanganan pengungsi dalam negeri di Indonesia antara lain:

a. Masing-masing daerah memiliki karakteristik berbeda sehingga penyelesaian masalahnya tidak bisa diseragamkan. Misalnya saja disebabkan oleh bencana alam, konflik horisontal, konflik vertikal. Kendala tersebut membutuhkan strategi khusus yang harus dipikirkan oleh pemerintah Indonesia Masalah pengungsi terkait dengan berbagai aspek sehingga solusinya memerlukan waktu lama, masih ada pemahaman keliru bahwa pengungsi adalah penerima bantuan saja sehingga menjadikan pengungsi tergantung bantuan.

b. Masalah penanganan pengungsi sering dirnanfaatkan oieh pihak tertentu sehingga rnengganggu kinerja penanganan pengungsi. Diperlukan waktu lama bagi pengungsi untuk menyesuaikan diri ke tempat asal.

Pengawasan dan penaganan terhadap pencari suaka ini Di Kota Makassar dilakukan dengan cara koordinasi antara Kantor Wilayah Kementerian Hukum dan HAM Sulawesi Selatan, Kantor Imigrasi Klas I Makassar, Rudenim Makassar, Polda Sulawesi Selatan, TNI atau Instansi Pemerintah dan masyarakat. Bentuk pengawasan Divisi Keimigrasian Kanwil Kementerian Hukum dan HAM Sulawesi bersama instansi terkait terhadap keberadaan dan aktifitas warga negara asing baik itu yang legal maupun ilegal ( antara lain pengungsi dan pencari suaka ) adalah sebagai berikut :

a. Pengawasan administratif adalah pengawasan yang dilakukan melalui penelitian surat-surat atau dokumen, berupa pencatatan, pengumpulan, pengolahan data dan penyajian maupun penyebaran informasi secara manual dan elektronik, tentang lalu lintas keberadaan dan kegiatan orang asing. Pengawasan bentuk ini di lakukan secara periodik setiap bulannya baik dlam bentuk rapat kerja, forum group discussion atau dalam bentuk pertemuan lainnya.

b. Pengawasan lapangan adalah pengawasan yang dilakukan berupa emantauan, patroli, proses dengan mengumpulkan bahan keterangan, pencarian orang dan alat bukti yang berhubungan dengan Tanda Pengenal Keimigrasian Pengawasan lapangan dapat dilakukan di tempat-tempat di mana beradanya orang asing berupa alat angkut, kantor perusahaan, hotel dan sejenisnya, pusat keramaian dan tempattempat hiburan, Community House serta yang lainnya.

Sumber data pengawasan lapangan diperoleh petugas dari Hasil engamatan, berupa wawancara, pelacakan, pembuntutan dan penyusupan, Hasil penilaian sumber data sebagaimana data-data dari sumber data pengawasan administrasi, Hasil penilaian dari laporan masyarakat, berita media massa, baik cetak maupun elektronik, Hasil laporan instansi pemerintah dan swasta, Hasil pengembangan semua sumber daya yang ada

Penanganan imigran ilegal pengungsi atau pencari suaka, di Kota Makassar $\mathrm{P}\{$ ihak keimigrasian bekerja sama dengan UNHCR dan IOM perwakilan Makassar, Namun di karenakan pemerintah Indonesia tidak mempunyai mekanisme penentuan status pengungsi yang dapat di jadikan standar prosedur operasional penangana pengungsi dan pencari suaka maka, selama ini badan PBB yang mengurusi Pencari suaka UNHCR lah yang memproses sendiri setiap permohonan status pengungsi di Indonesia termasuk pencari suaka yang berada di Kota Makassar dengan badan internasional IOM. Untuk imigran ilegal yang sudah maengantongi surat keterangan status pengungsi UNHCR di negara asalnya, Pihak Rudenim Makassar tidak akan mengakuinya. Mereka akan tetap mendapat tindakan keimigrasian. Sebagai upaya Penegakan hukum keimigrasian di indonesia dan di Kota Makassar. Penindakan keimigrasian ini dibedakan menjadi dua macam yaitu Tindakan keimigrasian dalam bentuk administratif dan Tindakan keimigrasian dalam bentuk Tindak Pidana Keimigrasian melalui proses pengadilan. Alasan dari pelaksanaan tindakan keimigrasian dalam Undang-Undang Keimigrasian yaitu melakukan kegiatan yang berbahaya atau patut diduga berbahaya bagi keamanan dan ketertiban umum, Tidak menaati peraturan perundang-undangan yang berlaku. Jenis-jenis tindakan administratif keimigrasian dapat berupa Pencantuman dalam daftar pencegahan atau 
penangkalan dan Pembatasan, perubahan atau pembatalan izin tempat tinggal

Sebagai negara hukum, Indonesia menempatkan norma hukum sebagai dasar fundamental bernegara. Diterbitkannya Peraturan Presiden Nomor 125 Tahun 2016 tentang Penanganan Pengungsi dari Luar Negeri, telah memberikan pedoman bagi Indonesia untuk menangani keberadaan pencari suaka dan pengungsi . Untuk menangani masalah pengungsi secara internasional terdapat aturan hukum mengenai pengungsi internasional dan konvensi-konvensi tersebut merupakan salah satu bentuk upaya perlindungan bagi pengungsi, yaitu, The 1951 Convention Relating to the Status of Refugees, The 1967 Protokol Relating to the Status of Refugees, The Convention Relating to the Status of Stateless Person (1954), Convention Governing the Specific Aspects of Refugees Problems In Africa (1969).

Di Indonesia terdapat dua organisasi Internasional sekaligus yang menangani masalah pengungsi, yaitu United Nations High Commissioner for Refugees (UNHCR) dan International Organization of Migration (IOM) yang perwakilannya terdapat di beberapa daerah di Indonesia, khususnya yang menampung pengungsi dan pencari suaka termasuk salah satunya di Kota Makassar. Selain itu Peraturan Direktur Jenderal Imigrasi Nomor IMI-0352.GR.02.07 Tentang Penanganan Imigran Ilegal yang Menyatakan Diri Sebagai Pencari Suaka atau Pengungsi menjadi acuan Instansi Keimigrasian Di kota Makassar dalam Penanganan terhadap orang asing yang menyatakan diri sebagai pencari suaka atau pengungsi pada saat masuk ke wilayah Kota Makassar. Rudenim Makasssar yang berwenang menangani masalah pencari suaka sesuai Peraturan Direktur Jenderal Imigrasi Nomor IMI-0352.GR.02.07 dalam melakukan tugasnya berkoordinasi dengan Kantor Imigrasi Klas I Makassar, Kanwil Kementerian Hukum dan HAM Sulawesi Selatan beserta instansi terkait antara lain Pemerintah Kota Makassar, Kepolisian Daerah Sulawesi Selatan dan lainnya. Penanganan terhadap orang asing yang menyatakan diri sebagai pencari suaka atau pengungsi pada saat masuk ke wilayah Kota Makassar dilakukan pada kesempatan pertama yaitu melakukan pengamanan dan pendataan, menghubungi perwakilan Negara Orang Asing bersangkutan, menghubungi IOM untuk fasilitas penampungan sementara, dan menghubungi UNHCR untuk penentuan statusnya.

Di Kota Makassar Imigran Ilegal yang datang Sebagai Pencari Suaka atau Pengungsi ditempatkan di ruang Deteni Imigrasi ( RUDENIM Makassar ) atau tempat lain. Pencari suaka dan Pengungsi dapat ditempatkan di tempat lain dalam hal Rumah Detensi Imigrasi atau Ruang Detensi Imigrasi telah melebihi daya tamping, Sakit dan memerlukan perawatan, akan melahirkan dilaksanakan berdasarkan persetujuan Direktur Jenderal Imigrasi atau Pejabat Imigrasi yang ditunjuk. Pencari suaka dan Pengungsi wajib mentaati ketentuan peraturan perundang-undangan, adat istiadat masyarakat setempat, Penempatan pencari suaka dan pengungsi di Ruang Detensi, Rumah Detensi, atau tempat lain dilaksanakan sesuai Standar Operasional Prosedur. Bagi Orang Asing yang sudah memiliki status Pengungsi dan pencari suaka ditempatkan di Tempat Penampungan Sementara (Community House) dan diwajibkan secara berkala 1 (satu) bulan sekali untuk melapor ke Kantor Imigrasi setempat. Ketentuan ini berlaku juga bagi para pemilik atau pengelola Tempat Penampungan Sementara (Community House) diwajibkan secara berkala 1 (satu) bulan sekali untuk melapor identitas dan jumlah Orang Asing yang sudah memiliki status pengungsi ke Kantor Imigrasi setempat..

Penerbitan Peraturan Direktur Jenderal Imigrasi tersebut membuat Rumah Detensi Imigrasi menampung seluruh pengungsi yang menyebabkan over capacity. Padahal, pada awalnya Rumah Detensi Imigrasi hanya mengurusi deteni. Deteni berdasarkan Pasal 1 ayat (35) Undang-Undang Nomor 6 Tahun 2011 Tentang Keimigrasian diartikan sebagai orang asing penghuni rumah detensi imigrasi (penampungan orang asing yang berada di Direktorat Jenderal Imigrasi) yang telah mendapatkan keputusan pendetensian dari pejabat imigrasi

Ada dua kategori orang asing yang ditempatkan di Rumah Detensi Imigrasi. Pertama, Imigran illegal yaitu adalah orang asing yang masuk ke dan atau berada di wilayah Indonesia tidak sesuai dengan ketentuan perundangundangan, biasanya berasal dari negara-negara yang sedang mengalami konflik dan bermaksud untuk mencari suaka ataupun mencari status pengungsi ke negara ketiga dengan melalui Indonesia sebagai negara transit namun ketika tiba di Indonesia tertangkap oleh petugas Imigrasi karena tidak dilengkapi dokumen keimigrasian yang lengkap kedua adalah WNA yang berada di wilayah indonesia melewati batas izinnya atau over stay namun belum di lakukan tindak deportasi dikarenakan kesulita hubungan dengan negara asal; ataupun WNA yang berda di wilayah Indonesia tidak sesuai peruntukannya misalnya WNA yang masuk dengan ijin kunjungan ternyata kedapatan melakukan aktivitas usaha atau bekerja.

Peraturan Direktur Jenderal Imigrasi Nomor IMI0352.GR.02.07 Tentang Penanganan Imigran Ilegal yang Menyatakan Diri Sebagai Pencari Suaka atau Pengungsi membuka pintu lebar dan memicu gelombang arus para pengungsi dan pencari suaka masuk ke wilayah Indonesia termasuk di Kota Makassar. Hal ini menyebabkan Rudenim Makassar Tidak Mampu menampungnya ( over kapasitas ), sebelumnya kewenangan pengawasan keimigrasian dilakukan oleh Kantor Imigrasi, namun sejak di keluarkannya Peraturan Presiden Nomor 125 Tahun 2016 dan Peraturan Direktur Jenderal Imigrasi Nomor IMI-0352.GR.02.07 menjadi tugas dan tanggung jawab Rudenim termasuk Rudenim Makassar . Namun peralihan kewenagan penanganan orang para pengungsi dan pencari suaka ini di ikuti dengan kewajiban Direktorat Jenderal Imigrasi menetapkan kebijakan yang menunjang tugas dan wewenang Rumah Detensi Imigrasi 
dalam melaksanakan Peraturan dimaksud. Mengingat secara kelembagaan belum adanya perubahan struktur organisasi sejak pelimpahan kewenangan Rumah Detensi Imigrasi dalam penanganan pencari suaka dan pengungsi. Oleh karena, belum adanya perubahan kelembagaan akan mempengaruhi berbagai unsur lainnya seperti ketatalaksanaan, infrastruktur, dan perencanaan dalam pelaksanaan tugas Rumah Detensi Imigrasi sebagai akibat banyaknya pengungsi yang harus ditangani Rumah Detensi Imigrasi dengan keterbatasan pegawai, sarana, dan prasarana di Rumah Detensi Imigrasi.

Penempatan para pengungsi dan pencari suaka ke rumah penampungan ini tentunya membutuhkan pengawasan dan pemantauan extrah sebab rata rata lokasi community house berada di tengah tengah masyarakat kota makassar sehingga rawan bersinggungan dengan masyarakat sekitar community house. Untuk melaksanakan pengawasan ini di adakan tugas bersama tim POA dengan menempatkan petugas khusus Rudenim Makassar, aparat keamanan, TNI dan Polri serta petugas dari IOM makassar yang berpos di setiap communty house yang ada di wilayah Kota Makassar.

2. Penyalahgunaan Izin Keimigrasian Oleh Pencari Suaka Di Kota Makassar

Sebagaimana yang telah diketahui bahwa Konvensi 1951 dan Protokol 1967 mengenai pengungsi hingga saat ini belum dilakukan proses ratifikasi oleh pihak Indonesia sebagai salah satu negara yang menerima kehadiran pengungsi berada di wilayahnya, utamanya sebagai negara transit bagi para pengungsi sebelum ditempatkan ke negara tujuan mereka. Pemerintah Indonesia juga telah melahirkan produk hukum dalam bentuk Peraturan Presiden Nomor 125 Tahun 2016 tentang Penanganan Pengungsi dari Luar Negeri (selanjutnya disingkat Perpres No. 125 Tahun 2016 tentang PPLN) sebagai landasan Pemerintah Indonesia menangani pengungsi yang berada di wilayahnya. Akan tetapi, Perpres yang dikeluarkan ini hanya berisi aturan terkait kewenangan pemerintah Indonesia dalam hal penempatan, dan pengurusan dokumen dari negara transit ke negara tujuan serta penjabaran hak dan kewajiban pengungsi selama berada di wilayah Indonesia. sehingga Perpres ini lahir memiliki kelemahan dalam hal penanganan pengungsi di Indonesia, khususnya terkait aturan jika terdapat pengungsi melakukan perbuatan penyalahgunaan terhadap izin keimigrasian dan perbuatan yang melanggar hukum nasional lainnya diIndonesia. Lebih jelasnya jika dicermati dalam Perpres tersebut tidak terdapat tiga komponen yang spesifik mengatur terkait pengungsi di Indonesia yaitu pertama, dalam Perpres tidak dijabarkan terkait jumlah pengungsi yang diterima di Indonesia, sehingga terbukti saat ini terjadi Over Capacity dikarenakan tempat yang disediakan tidak mampu menampung besarnya jumlah pengungsi yang memasuki wilayah Indonesia kedua ialah tidak adanya penjabaran aturan terkait batasan waktu bagi para pengungsi berada di wilayah Indonesia, hal ini merupakan ketimpangan apabila pengungsi tersebut tidak diterima atau ditolak oleh negara yang menjadi tujuan mereka. Dengan kata lain,pengungsi yang ditolak oleh negara tujuan akan tetap menetap di Indonesia sampai ada pihak negara yang menerima kehadirannya. Kemudian yang ketiga adalah tidak adanya aturan secara eksplisit dan jelas terkait pengungsi yang melakukan suatu perbuatan yang dikategorikan sebagai perbuatan melawan hukum nasional ataupun tindak pidana di Indonesia. Kelemahan dari Perpres No. 125 tahun 2016 ini membuat pemerintah terbatas dalam penanganan pengungsi di Indonesia, sehingga banyak kasus pelanggaran baik itu pelanggaran imigrasi maupun suatu perbuatan yang masuk dalam kategori tindak pidana, langsung diambil alih oleh pihak UNHCR maupun IOM. Padahal sudah jelas bahwa dalam aturan internasional diuraikan bahwa pengungsi baik di negara tujuan maupun di negara transit harus mematuhi aturan yang berlaku di wilayah mereka tempati. Sebagaimana yang tercantum dalam Pasal 35 Konvensi 1951

Adanya dasar hukum dalam konvensi 1951 tersebut yang menyatakan bahwa pengungsi wajib menyesuaikan diri dengan hukum nasional yang berlaku di Indonesia, secara tidak langsung telah menyimpulkan bahwa bagi seorang pengungsi yang melakukan tindakan - tindakan yang tidak sejalan dengan aturan di Indonesia, maka pengungsi dapat dikenakan sanksi sesuai dengan tindakan yang diperbuat tersebut. Namun, pada prinsipnya Indonesia dan negara-negara lainnya tidak akan mengenakan sanksi pidana terhadap pengungsi yang secara langsung datang dari suatu wilayah dimana kehidupan atau kebebasan mereka terancam dengan alasan bahwa mereka memasuki atau berada di wilayah mereka tanpa izin, dengan syarat pengungsi tersebut sesegera mungkin melaporkan diri kepada pihak yang berwajib dan memberikan alasan yang mendasar mengenai masuknya atau keberadaan mereka secara tidak sah di wilayah itu

Jumlah pengungsi yang semakin meningkat dan menetap dalam kurun waktu yang cukup lama khususnya di Kota Makassar ini dapat berpotensi untuk memberikan kerugian kepada pemerintah dari segi sosial khususnya. Tidak jarang para pengungsi ini berperilaku yang tidak sesuai dengan norma yang berlaku di Kota Makassar bahkan melakukan tindakan-tindakan yang melanggar hukum nasional di Indonesia. Tindakan-tindakan yang melanggar hukum berupa pencurian, pelecehan seksual, penyalahgunaan narkoba, penganiayaan, Hal ini dibuktikan dengan jumlah kasus pelanggaran izin keimigrasian yang dilakukan oleh pengungsi yang terjadi di kota Makassar. Rumah Detensi Imigrasi Kota Makassar merilis data beberapa WNA dengan status pengungsi yang melakukan tindak pidana selama berada di Kota Makassar yang dilengkapi dengan kondisi atau penempatan pengungsi tersebut saat ini Adapun bentukbentuk pelangaran yang umuimnya di lakukan pencari suaka yang terjadi di kota Makassar, yaitu:

a. Berada di wilayah Indonesia secara Illegal (Tidak Sah) 
b. Perbuatan yang melanggar KUHP pidana semacam pencuria, pemerkosaan, pengaiayaan dan lainnya dalam aturan ini.

c. Perusakan fasilitas umum (sarana dan prasarana yang disediakan kepada pengungsi)

d. Melakukan aktifitas yang bertentangan dengan aturan keimigrasian seperti bekerja, dan memiliki hak milik tanpa memenuhi persyaratan yang berlaku

e. Melanggar Beberapa norma hukum lainnya yang berlaku di indonesia

Perbuatan Pengungsi atau Pencari suaka di Kota Makassar yang melanggar ketentuan Ketentuan Hukum Nasional, misalnya Hukum Pidana penegakan hukumnya diserahkan kepada pihak yang berwenang yaitu institusi yang terkait dengan proses yustisia Polri, Kejaksaan dan Pengadilan dengan landasan hukum Pasal 2 KUHP yang menyatakan bahwa ketentuan-ketentuan dalam UndangUndang Indonesia berlaku bagi tiap orang yang dalam Indonesia melakukan sesuatu perbuatan yang dapat dikenakan hukuman (apabila termasuk sebagai peristiwa hukum). Pasal ini menjadi perluasan hukum pidana di Indonesia yang berlaku bagi siapa saja dan dimana saja dengan meletakkan prinsip territorial dalam pemberian sanksinya. Kata "tiap orang" dalam pasal juga menitikberatkan kepada siapa saja, baik itu WNI sendiri maupun bangsa asing, dengan tidak membedakan jenis kelamin, ras, agama, kedudukan, dan pangkat.

Para pencari suaka yang telah dinyatakan sebagai pengungsi dan memiliki kartu UNHCR telah menandatangani surat pernyataan sebelumnya. Adapun beberapa poin penting dalam kesepakatan itu, yang salah satu poinnya pengungsi dilarang bekerja untuk mendapatkan upah, sesuai Peraturan Dirjen Imigrasi No IMI-1489.UM.08.05 Tanggal 17 September 2010 tentang Penanganan imigran illegal. Setelah didata pengungsi dan memiliki kartu UNHCR, Karena keberadaannya di Indonesia adalah menunggu untuk pemukiman kembali ke negara penerima suaka atau pulang kembali ke negaranya secara sukarela apabila telah aman. Banyak di temukan pengungsi atau pencri suaka yang memiliki kendaraan bermotor selama di Kota Makassar. Ketika diadakan pemantauan ke lapangan mereka beralasan kendaraan ini dipakai untuk menunjang aktifitas sehari hari di sekitar community house mereka serta digunakan untuk antar jemput anak mereka yang bersekolah di sekitar wilayah community house mereka. Berkaitan dengan kepemilikan kendaraan hal ini melanggar ketentuan kepemilikan harta benda di indonesia, seperti rumah, tanah dan kendaraan bergerak lainnya dan sudah barang tentu izin penggunaan kendaraan bermotor ini tidak di perbolehkan untuk pengungsi dan pencari suaka berkaitan dengan Izin Mengendarai / SIM yang syaratnya harus mempunyai dokumen resmi kependudukan yang mana status ini tidak dimiliki oleh para pengungsi dan pencari suaka Terkait pelanggarannya, Rudenim Makassar memberikan sanksi teguran dan pembinaan serta membuat pernyataan tidak akan mengulangi pelanggarannya. Rudenim Makassar telah melakukan sosialisasi kewajiban dan larangan bagi pengungsi luar negeri di 25 akomodasi pengungsi yang tersebar di Kota Makassar, yang di antaranya berisi ketentuan Direktorat Jenderal Imigrasi yang harus dipatuhi para pengungsi, seperti harus tinggal di tempat yang telah ditentukan Ditjen Imigrasi, pengungsi tidak boleh berada di sekitar bandara atau pelabuhan, tidak boleh bekerja atau mendapatkan upah, serta tidak boleh mengemudikan kendaraan bermotor. Para pengungsi luar negeri juga diwajibkan melaporkan diri secara berkala, sekali sebulan di kantor Rudenim Makassar.

Pada dasarnya Pemerintah Indonesia masih tetap memiliki kewenangan dan peran dalam melakukan pengawasan terhadap pengungsi yang melakukan perbuatan yang dikategorikan sebagai tindak pidana, dengan berlandaskan bahwa pengungsi telah menetap dan berada di wilayah Indonesia. Pengawasan tersebut perlu dilakukan untuk mencegah tindakan-tindakan yang dapat memicu terjadinya pelanggaran peraturan yang berlaku. Hal ini dikarenakan telah muncul masalah seperti khususnya terkait pelanggaran keimigrasian yang dilakukan oleh para pengungsi. Namun kenyataan yang terjadi dalam prakteknya, pengungsi yang diduga maupun telah melakukan tindak pidana tidak diselesaikan sesuai dengan prosedur penyelesaian perkara pidana pada umumnya yang sesuai ketentuan hukum nasional di Indonesia melainkan diselesaikan secara komprehensif internal terhadap lembaga atau instansi yang dinaungi oleh UNHCR itu sendiri.

Pengawasan terhadap pengungsi di Indonesia khususnya di kota Makassar pada dasarnya juga diikuti dengan penegakan hukum yang cepat dan tepat atas setiap pelanggaran keimigrasian dengan cara koordinasi pengawasan orang asing dilakukan secara terpadu. Pengungsi yang telah berada dan menetap di Rudenim Makassar, tak kadang menimbulkan persoalan bahkan lebih mengacu kepada suatu perbuatan tindak pidana. sebenarnya perbuatan pengungsi banyak dikatakan melakukan tindak pidana oleh masyarakat namun secara spesifik itu belum bisa dikatakan sebagai tindak pidana apabila tidak terjadi proses penyelesaian oleh pihak kepolisian, terkadang kepolisian yang tidak menerima atau melakukan pemeriksaan lebih lanjut terhadap perbuatan pengungsi dan langsung menyerahkan kembali kepada pihak Rudenim Makassar. Kemudian, Indonesia belum meratifikasi Konvensi 1951 tetapi tetap menerima pengungsi masuk ke wilayahnya sehingga konsekuensinya banyak yang beranggapan hal inilah mendasari pengungsi mendapatkan perlakuan khusus. Namun, jika dikaitkan antara hukum pidana dengan Indonesia yang belum meratifikasi Konvensi 1951 dan Protokol 1967 tentang Pengungsi tersebut tidak memiliki keterkaitan, utamanya dalam penerapan hukum nasional atau hukum pidana di Indonesia.

Dilain sisi, benar kehadiran dalam Pasal 2 KUHP menyatakan bahwa bagi siapa yang melanggar hukum yang berlaku di Indonesia dapat dikenakan hukuman atau sanksi baik itu WNI maupun WNA. Tetapi perlu diketahui, pengungsi yang meminta bantuan di negara lain 
baik itu di negara transit maupun negara tujuan dianggap tidak memiliki kewarganegaraan. Dengan kata lain, pengungsi di kota Makassar tidak memiliki kewarganegaraan, terbukti mereka tidak memiliki paspor maupun visa penanda mereka memiliki kewarganegaraan. Sehingga berdasarkan hal ini pengungsi tidak dapat langsung dikenakan Pasal 2 KUHP dengan berlandaskan bahwa mereka orang yang meminta bantuan dan tidak memiliki kewarganegaraan, karena kewarganegaraan pada negara asalnya telah gugur dan kewarganegaraan yang baru akan diberikan pada saat diterima di negara tujuannya.

Contoh kasus di mana pihak Rudenim Makassar menerima seorang pengungsi yang diserahkan langsung oleh pihak Kepolisian. Pengungsi ini dinyatakan telah ditemukan oleh Kepolisian sedang memakai narkoba sehingga dilakukan penangkapan dan penahanan oleh Kepolisian Namun kembali lagi, pihak kepolisian menyerahkan pengungsi tersebut di dalam Rudenim Makassar. Pihak Rudenim Makassar yang mendapatkan seorang pengungsi melakukan tindak pidana bahkan yang diserahkan oleh Kepolisian tetap akan dilakukan proses pemeriksaan lebih lanjut. Setelah terbukti melakukan kesalahan di wilayah Indonesia, pihak Rudenim Makassar berdasarkan kordinasi antar lembaga pengurus imigrasi dapat melakukan tindakan yang membuat jera pengungsi agar tidak melakukan perbuatan pelanggaran lagi. Tindakan yang dilakukan oleh Pihak Rudenim ialah melakukan pengurungan pengungsi dialam Rudenim itu sendiri, pemindahan pengungsi ke Rudenim lainnya,dan penghentian bantuan fasilitas. Pengungsi yang melakukan perbuatan yang diduga melanggar hukum pidana di Makassar, akan ditahan dan dikurung dalam sebuah sel yang hanya muat untuk satu orang, yang bertujuan untuk memberikan efek jera kepada pengungsi karena akan merasa terisolasi dibandingkan pengungsi lainnya, dimana mereka baru ilepas jika telah memberikan pernyataan atau kesepakatan untuk tidak mengulangi lagi perbuatannya, bisa dalam bentuk surat pernyataan ataupun pengakuan langsung.

Faktor - Faktor Yang Mempengaruhi Penyalahgunaan Izin eimigrasian Oleh Pencari Suaka Di Kota Makassar

Indonesia dipilih sebagai negara transit bagi para pengungsi dan pencari suaka, dikarenakan pertama, Indonesia memiliki wilayah laut yang luas dangaris pantai yang panjang, namun, tidak didukung oleh aturan hukum yang tegas. Kedua,posisi Indonesia sangat lemah dalam mengatasi masalah para pencari suaka dan pengungsi dari negara lain karena tidak memiliki peraturan nasional yang secara khusus membahas masalah tersebut. Ketiga,kurangnya sarana dan prasarana yang dimiliki dalam penanganan pengungsi dan pencari suaka. Keempat, keberadaan UNHCR di Jakarta menjadi dayatarik pengungsi. Kelima, kultur atau budaya masyarakat Indonesia yang dikenal dengan keramahannya, menimbulkan kesan masyarakat Indonesia dapat dengan mudah menerima kedatangan dan keberadaan para pengungsi.
Pengaturan pencari suaka dan pengungsi selayaknya ditempatkan dalam perundang-undangan keimigrasian karena masalah pencari suaka dan pengungsi merupakan masalah (status keimigrasian) orang asing, yang menyentuh aspek intemasional. Penanganan terhadap pengungsi, imigran dan pencari suaka mengalami beberapa kendala dalam proses penanganan terhadap mereka, yaitu Kendala Internal; tidak adanya standar baku dalam peraturan perundang-undangan mengenai penanganan imigran gelap. Kekosongan hukum yang mengatur secara komprehensif pencari suaka dan pengungsi di dalam hukum positif Indonesia, melemahkan penanganan, pengawasan dan penyelesaian pelanggaran izin keimigrasian serta melemahkan koordinasi antar instansi di lapangan. Kekurangan fasilitas karantina imigrasi untuk menampung para pencari suaka dan pengungsi akibat Keterbatasan dana rutin Kendala Eksternal. Pemerintah Daerah keberatan menerima beban tambahan kedatangan orang-orang asing bermasalah. Perbedaan yang seringkali tajam antara kultur daerah dan kultur orang asing pengungsi potensial mendatangkan konflik sosial. Timbul kecemburuan sosial terbadap pengungsi mendapat bantuan kemanusiaan gratis berupa tempat tinggal dan biaya hidup, sedangkan warga setempat hidup dalam keadaan kekurangan. Warga tidak menyadari bahwa bantuan itu bukan berasal dari pemerintah, tapi dari UNHCR dan atau IOM.

\section{Kondisi Rudenim}

Rumah Detensi Imigran (Rudenim) merupakan tempat penampungan imigran setelah melalui tes kesehatan dan wawancara untuk mengetahui tujuannya ke Indonesia. Hingga saat ini, Indonesia hanya memiliki 14 Rudenim yang tersebar di beberapa wilayah provinsi. Rudenim ini dihuni oleh ribuan orang pengungsi, sehingga tiap rudenim mengalami over capacity. Keadaan over capacity ini memaksa penempatan pengungsi dan pencari suaka ini di tempatkan di yang berlokasi ditengah - tengah masyarakat.dalam bentuk rumah penanmpungan sementara ( Community House ) Dalam segi pengamanan, jumlah petugas penjaga di Rudenim tidak dapat bekerja sendiri secara maksimal dikarenakan perbandingan antara penjaga keamanan dengan jumlah pengungsi yang mencapai ratusan orang.

Rudenim Makassar berkoordinasi dengan IOM Makassar telah menyediakan beberapa tempat untuk pengungsi tinggal sementara di kota Makassar, Penempatan pengungsi ini didasarkan pada tiga pertimbangan yaitu : pertama, seluruh pengungsi pada awalnya akan ditempatkan di Rudenim, tetapi dengan kondisi jumlah pengungsi yang masuk ke Kota Makassar sangat banyak sehingga diantara mereka dialihkan atau ditampung ke rumah penampungan sementara ( community house) . Kedua yaitu pengungsi ditempatkan di Rudenim ialah pengungsi yang telah akan segera dipindahkan atau dikirim ke negara tujuan mereka dikarenakan telah memperoleh persetujuan oleh pihak negara tersebut, sehingga pengurusan berkas, dokumen dan visa lebih mudah dijangkau oleh pengungsi karena 
berada di dekat kantor pusat keimigrasian.Ketiga ialah, pihak UNHCR dan pihak Keimigrasian lebih memilih menempatkan para pengungsi yang telah masuk kedalam daftar pengungsi bermasalah, utamanya yang telah melakukan perbuatan yang perlu mendapatkan pengawasan lebih dan penindakan oleh pihak Rudenim, salah satunya ialah perkara Penyalahgunaan Izin Keimigrasian yang dilakukan oleh pengungsi atau pencari suaka di Kota Makassar.

\section{Celah Hukum Nasional}

Saat ini penanganan dan pengawasan masalah pengungsi masih sangat terbatas, tepatnya dalam hal sumber daya manusia, anggaran, sarana dan prasarana Hukum Nasional Indonesia memiliki keterbatasan dan kekosongan hukum dalam menangani masalah pengungsi yang masuk ke Indonesia sehingga menyebabkan kordinasi yang lemah antar institusi di lapangan. Celah hukum yang dilihat oleh pengungsi sebagai alibi dalam melakukan Penyalahgunaan izin keimigrasian, dikarenakan mereka mengetahui bahwa saat ini Indonesia masih belum melakukan proses ratifikasi Konvensi 1951 dan Protokol 1965 tentang pengungsi. Selain itu, didukung oleh Pemerintah Indonesia yang tidak mengeluarkan peraturan-peraturan baik itu yang bersifat Lex Specialis untuk mengatur terkait pengungsi yang melakukan pelanggaran di Indonesia, yang dikeluarkan hanya Perpres yang lebih mengatur mengenai kewenangan, hak dan kewajiban pengungsi selama berada di Indonesia. Bahkan, status pengungsi tidak dijelaskan secara eksplisit di dalam Undang-Undang Nomor 6 Tahun 2011 tentang Keimigrasian, sehingga bagi para pengungsi yang melakukan Penyalahgunaan izin keimigrasian tidak bisa dijatuhkan sanksi atau hukuman pelanggaran imigrasi sehingga pihak keimigrasian tidak bisa secara langsung menangani penyelesaian permasalahan pengungsi dan pencari suaka tersebut.

3. Lambatnya Penempatan Ke negara Tujuan

Setelah pengungsi tiba di Indonesia akan ditempatkan di beberapa kota yang memiliki Rudenim untuk tinggal dan hidup sementara waktu hingga dilanjutkan penempatan ke negara tujuan mereka. Indonesia memang sering dijadikan sebagai negara transit oleh pihak PBB untuk para pengungsi sebelum dikirimkan ke negara tujuan mereka seperti Amerika Serikat, Australia, Kanada dan Selandia Baru. Penempatan pengungsi ke negara tujuan mereka ini harus menunggu hingga berkas - berkas mereka di terima dan telah mendapatkan persetujuan oleh negara yang bersangkutan, dan menyatakan bahwa mereka yang mengajukan untuk menetap di wilayah negara tersebut telah diterima. Proses penempatan ke negara tujuan ini yang terkadang membutuhkan waktu yang cukup lama, dan membuat pengungsi harus menunggu di negara transit hingga tiba penempatan negara tujuannya. Hal ini menjadi pemicu penyalahgunaan Izin Keimigrasian di Kota Makassar adanya kejenuhan dari pengungsi dan pencari suaka yang berada di kota Makassar akibat tidak adanya kepastian status mereka. Mereka kebingungan dalam masa penantian bertahun tahun untuk di kirim ke negara tujuan mereka tidak dapat berbuat apa - apa, keseharian hanya makan dan tidur, bepergian di batasi, kerja tidk di perbolehkan. Tidak maksimalnya penyediaan sarana pemukiman yang layak menjadi keluhan utama pengungsi dan pencari suaka misalnya, minimnya penerangan ( listrik), ketersediaan air bersih, sarana dan prasarana pemukiman, tempat ibadah, olah raga pendidikan dan tempat bermain untuk anak.

Akhirnya Secara umum patut disadari bahwa, walaupun pengungsi dan pencari suaka di Indonesia merupakan salah satu bentuk illegal migration. Yang menyatakan diri sebagai pengungsi dan pencari suaka dengan memanfaatkan kondisi Indonesia yang tidak memiliki spektrum hukum yang jelas dalam penanganan isu imigran illegal serta, Indonesia bukan negara yang ikut meratifikasi Konvensi Pengungsi 1951 atau Protokol 1967 sehingga pemerintah Indonesia tidak mempunyai kewajiban dan tanggungjawab langsung dalam penanganan masalah pengungsi dan pencari suaka Tetapi, Indonesia secara tidak langsung memiliki kewajiban untuk turut mengambil peran terhadap permasalahan imigran ilegal, dengan mempertimbangkan aspek Hak Asasi Manusia (HAM) para imigran ilegal.

\section{KESIMPULAN DAN SARAN}

Hasil penelitian ini dapat disimpulkan bahwa Indonesia bukan negara yang ikut meratifikasi Konvensi Pengungsi 1951 atau Protokol 1967 sehingga pemerintah Indonesia tidak mempunyai kewajiban dan tanggungjawab langsung dalam penanganan masalah pengungsi dan pencari suaka Tetapi, Indonesia secara tidak langsung memiliki kewajiban untuk turut mengambil peran terhadap permasalahan imigran ilegal, dengan mempertimbangkan aspek Hubungan Luar Negeri serta Hak Asasi Manusia (HAM) .Pemerintah Indonesia tidak mempunyai aturan khusus yang mengatur mengenai perlindungan dan penanganan pengungsi dan pencari suaka. Undang-Undang Nomor 6 Tahun 2011 tentang Keimigrasian, Peraturan Presiden Nomor 125 Tahun 2016 tentang Penanganan Pengungsi dari Luar Negeri secara tegas tidak mengatur tentang bagaimana penanganan, pengawasan dan tindakan hukum terhadap penyalahgunaan izin keimigrasian serta pelanggaran norma hukum lainnya di wilayah indonesia khususnya Kota Makassar yang dilakukan oleh pengungsi dan pencari suaka. . Pengaturan Penanganan Pencari Suaka dan Pengungsi serta penyelesaian penyalahgunaan izin keimigrasian yang mereka lakukan selayaknya dilakukan secara komprehensif dalam peraturan perundang undangan keimigrasian, Namun jangan di tafsirkan bahwa indonesia telah meratifikasi Konvensi 1951 dan Protokol 1967. Pengaturan itu berupa adopsi prinsip kemanusiaan penanganan pencari suaka dan pengungsi ke dalam hukum nasional, minus kewajiban yang memberatkan negara. Misalnya pemberian status keimigrasian temporer 
akan memudahkan pengendalian dan pengawasan orang asing. Seperti saat ini, keberadaan mereka di Indonesia seakan kurang terkontrol karena aparatur hanya memiliki data kuantitatif, sedangkan data kualitatif dimiliki UNHCR.

\section{DAFTAR PUSTAKA}

Adjat Sudrajat Hafid. 2012. Formalitas Keimigrasian. Direktorat Jenderal Imigrasi Departemen Hukum dan HAM. Penerbit : PT. Utama Jakarta

Amir Ilyas, 2012. Asas-Asas Hukum Pidana, Rangkang Education Yogyakarta dan Pukap Indonesia, Yogyakarta

Charles Christia. 2015. Hukum Keimigrasian Bagi Orang Asing Di Indonesia. Jakarta. Penerbit Sinar Grafika

Edy, E., Hamka, H., \& Maldun, S. (2019). Implementasi Kebijakan Peraturan Presiden No 87 Tahun 2016 Tentang Satuan Tuagas Sapu Bersih Pungutan Liar. Jurnal Paradigma Administrasi Negara, 1(1), 32-37

Imam Santoso, 2007. Perspektif Imigrasi, Perum Percetakan Negara Republik Indonesia.

Jazim Hamidi, 2015. Hukum Keimigrasian, Jakarta Sinar Grafika

Lawrence M Friedmann. 2002. Pertumbuhan dan Perkembangan Masyarakat. Bandung. Penerbit : Rineka Cipta

Moelyatno, 2004. Asas-Asas Hukum Pidana. Jakarta: Rineka Cipta

Rosmawati, 2015, "Perlindungan terhadap Pengungsi/Pencari Suaka di Indonesia menurut Konvensi 1951 dan Protokol 1967”. Kanun Jurnal Ilmu Hukum

Ruslan Renggong, 2016, Hukum Pidana Khusus, Jakarta, Prenadamedia Group.

Varagur, Krithka 2017, Indonesia atasi Masalah Pengungsi dengan Peraturan Presiden, 28 Januari, dilihat Juni 2019, https://www.voaindonesia.com/a/ri-atasi-pengungsidengan-keppres-/3696412.html

Yoyok Adi Saputra. 2009. Penegakan Hukum Keimigrasian terhadap pelanggaran Izin Keimigrasian Undang-undang Nomor 9 Tahun 1992. Penerbit : USU Repository, 